\title{
VIOLÊNCIA CONTRA PESSOAS IDOSAS NO RIO GRANDE DO SUL ENTRE
}

\section{E 2018}

Iride Cristofoli Caberlon SBGG/ABEn RS grupo de Interesse em Enfermagem Gerontológica.

E-mail: iridec27@gmail.com

Prof. Dr. Ângelo José Gonçalves Bós - Orientador - IGG/PUCRS. E-mail: angelo.bos@pucrs.br

\section{RESUMO}

Introdução: Violência contra a pessoa é registrada no Sistema de Informação de Agravos de Notificação (SINAN) do Ministério da Saúde (MS) desde 2011. A violência contra a pessoa idosa está enquadrada na Lei 10.741/2003. Objetivo: caracterizar os tipos de violência contra pessoas idosas no Rio Grande do Sul (RS) registrados no SINAM/MS. Métodos: Trata-se de estudo exploratório, descritivo com abordagem quantitativa de dados disponibilizados pelo MS na página http://sinan.saude.gov.br ocorridos entre 2015 e 2018. Resultados: Foram identificados 6.321 casos de violência em pessoas com 60 anos e mais no período, sendo 3.889 (61,5\%) do sexo feminino e a maioria brancos $5235(82,8 \%)$. Os tipos de violência registrados em ordem de frequência foram: física $(52,7 \%)$ psicológica/moral (32\%), negligência/abandono $(27,4 \%)$, financeira $(7,7 \%)$, sexual (2\%), assédio sexual $(0,7 \%)$ e outros tipos de violência (10,3\%). A violência foi praticada em maior frequência pela força corporal/espancamento $(36,6 \%)$, enforcamento $(7 \%)$ e tortura $(1,6 \%)$. Os principais agressores foram: filhos (31,5\%), cônjuge (11\%), conhecidos $(7,8 \%)$, desconhecidos (7\%), cuidador $(0,4 \%)$ e irmão(a) (0,38\%). Destaca-se a lesão autoprovocada em $19,6 \%$ e a violência repetida em $44,2 \%$. A violência ocorreu na própria residência $(81,9 \%)$, via pública $(6,5 \%)$ e outros 261 (4,1\%). Conclusão: Observamos uma possível subnotificação de violências registradas. É fundamental que todos os profissionais de saúde, incluindo enfermeiros, médicos, assistentes sociais sejam capacitados para reconhecer as situações de violência. A notificação da violência permite encaminhar a vítima aos órgãos competentes, para garantir a proteção, o rompimento do ciclo de violência, assegurando seus direitos à vida, saúde e bem-estar.

Palavras-chave: Pessoa idosa. Violência. Tipos. Agressor. RS 